\title{
Proses Pembentukan Kata Dalam Kumpulan Cerpen Cinta Paling Rumit Karya Boy Candra
}

\author{
Intan Peonnyta Oktaviani Putri ${ }^{*}$, I Wayan Simpen, Ni Putu N. Widarsini \\ Sastra Indonesia, Fakultas Ilmu Budaya, Universitas Udayana \\ [intanpeonnyta3@gmail.com] \\ *Corresponding Author
}

\begin{abstract}
This research "The Process of Forming Words in Short Story Collection Cinta Paling Rumit Karya By Candra" This research has a purpose was to know the formation of words which is affixation, reduplication, and composition in the short story collection Cinta Paling Rumit by Boy Candra. The theory used in this research is morphological theory. In the process of collecting the data are used the method of reffering to tapping techniques, proficient non-invulment listening techniques, and note-taking techniques. Then in analyzing data, the methods and techniques used are the agih methods with the direct elements technique, the advanced techniques used are sloping techniques, the substitution techniques, and repetition techniques. Besides using the agih method in process of analyzing data, this research also uses quantitative methods. Meanwile, the method of presenting the results data analysis uses informal methods and formal methods. In this research found affixation, the reduplication, and composition. The affixation found were 681 words $(31 \%)$, reduplication found were 150 words $(7 \%)$, and the composition found were 93 word (4\%).
\end{abstract}

Keywords: word formation, Cinta Paling Rumit, and Boy Candra

\begin{abstract}
Abstrak
Penelitian ini berjudul "Proses Pembentukan Kata dalam Kumpulan Cerpen Cinta Paling Rumit Karya Boy Candra". Tujuan penelitian ini adalah untuk mengetahui pembentukan kata yang meliputi afiksasi, reduplikasi, dan komposisi dalam kumpulan cerpen Cinta Paling Rumit karya Boy Candra. Teori yang digunakan dalam penelitian ini adalah teori morfologi. Dalam proses pengumpulan data menggunakan metode simak dengan teknik sadap, teknik simak bebas libat cakap, dan teknik catat. Kemudian dalam menganalisis data, metode yang digunakan adalah metode agih dengan teknik bagi unsur langsung (BUL). Teknik lesap, teknik ganti, dan teknik ulang digunakan sebagai teknik lanjutan. Selain menggunakan metode agih dalam proses menganalisis data, penelitian ini juga menggunakan metode kuantitatif. Sementara itu, metode informal dan metode formal digunakan untuk menyajikan hasil analisi data. Penelitian ini menemukan afiksasi, reduplikasi, dan komposisi. Afiksasi yang ditemukan adalah sebanyak 681 kata (31\%), reduplikasi 150 kata (7\%), dan komposisi ini sebanyak 93 kata (4\%).
\end{abstract}

Kata kunci: pembentukan kata, Cinta Paling Rumit, Boy Candra 


\section{Latar Belakang}

Bahasa dibutuhkan manusia sebagai sarana berkomunikasi antarsesama. Bahasa juga merupakan salah satu unsur penting dalam karya sastra. Dalam karya sastra, bahasa berperan sebagai sarana pengungkapan dan penyampaian pesan yang hendak disampaikan penulisnya. Terdapat berbagai jenis karya sastra. Salah satu di antaranya adalah cerpen.

Menurut Kamus Besar Bahasa Indonesia daring, cerpen atau cerita pendek adalah suatu bentuk prosa naratif fiktif yang cenderung padat dan langsung pada tujuannya. Kumpulan cerpen adalah sebuah buku yang terdiri atas beberapa judul cerpen berbeda, baik dari penulis yang sama maupun penulis yang berbeda. Salah seorang penulis yang menciptakan karya sastra berupa kumpulan cerpen ialah Boy Candra.

Penelitian ini menggunakan salah satu karya Boy Candra yang berupa kumpulan cerpen yang berjudul Cinta Paling Rumit sebagai sumber data. Kumpulan cerpen ini terbit pada Februari 2018. Kumpulan cerpen ini terdiri atas 329 halaman dan memuat 22 cerita. Dalam penelitian ini digunakan teori morfologi. Morfologi adalah bagian ilmu bahasa yang mempelajari seluk beluk struktur kata terhadap golongan dan arti kata (Ramlan, 1985:2). Bahasa dalam karya sastra dituangkan dalam bentuk kata-kata. Dalam bahasa Indonesia, kata dibentuk melalui proses pembentukan kata. Proses pembentukan kata adalah proses pembentukan kata-kata dari bentuk lain yang merupakan bentuk dasarnya (Ramlan, 1985:27). Menurut Chaer (2012:25), proses pembentukan kata pada dasarnya adalah proses pembentukan kata dari sebuah bentuk dasar melalui pembubuhan afiks (dalam proses afiksasi), pengulangan (dalam proses reduplikasi), penggabungan (dalam proses komposisi), dan lain-kain. Penelitian ini hanya dianalisis tiga proses pembentukan kata, yaitu afiksasi, reduplikasi, serta komposisi atau pemajemukan.

Penulis memilih kumpulan cerpen tersebut sebagai sumber data penelitian karena ingin mengetahui dan memahami lebih dalam lagi tentang proses afiksasi, proses reduplikasi, dan proses pemajemukan yang ada di dalam kumpulan cerpen tersebut. Dalam kumpulan cerpen ini juga terdapat proses pembentukan kata yang bervariasi sesuai dengan yang hendak diteliti. Alasan tersebutlah yang melatarbelakangi penulis melakukan penelitian mengenai proses pembentukan kata dalam kumpulan cerpen karya Boy Candra yang berjudul Cinta Paling Rumit.

\section{Pokok Permasalahan}

Berdasarkan latar belakang di atas, dapat dirumuskan permasalahan dalam penelitian ini adalah sebagai berikut.

a. Afiksasi apa sajakah yang terdapat dalam kumpulan cerpen Cinta Paling Rumit karya Boy Candra?

b. Reduplikasi apa sajakah yang terdapat dalam kumpulan cerpen Cinta Paling Rumit karya Boy Candra?

c. Komposisi apa sajakah yang terdapat dalam kumpulan cerpen Cinta Paling Rumit karya Boy Candra?

\section{Tujuan Penelitian}

Penelitian ini secara umum bertujuan untuk memberikan sumbangan pengetahuan dan untuk memperoleh data kebahasaan di bidang morfologi. Selain itu, penelitian ini juga bertujuan untuk memberikan tambahan pengetahuan mengenai proses pembentukan kata dalam kumpulan cerpen Cinta Paling Rumit karya Boy Candra. Penelitian ini secara khusus memiliki tujuan untuk mengetahui proses-proses sebagai berikut.

a. Afiksasi yang terdapat dalam dalam kumpulan cerpen Cinta Paling Rumit 
karya Boy Candra yang mencakup prefiksasi, infiksasi, sufiksasi, konfiksasi, dan simulfiksasi.

b. Reduplikasi yang terdapat dalam kumpulan cerpen Cinta Paling Rumit karya Boy Candra yang mencakup reduplikasi seluruh, reduplikasi sebagian, reduplikasi yang berkombinasi dengan pembubuhan afiks, dan reduplikasi dengan perubahan fonem.

c. Komposisi yang terdapat dalam kumpulan cerpen Cinta Paling Rumit karya Boy Candra yang mencakup komposisi nominal dan komposisi adjektival.

\section{Metode Penelitian}

Metode dan teknik pengumpulan data yang digunakan dalam penelitian ini adalah metode simak. Selain itu, teknik sadap digunakan sebagai teknik dasar dan teknik simak bebas libat cakap dan teknik cata sebagai teknik lanjutan. Metode agih dan metode kuantitatif digunakan sebagai metode analisis data, sedangkan teknik yang digunakannya adalah teknik bagi unsur langsung (BUL), teknik lesap, teknik ganti, dan teknik ulang digunakan sebagai teknik dasarnya. Hasil analisis data disajikan dengan mengunakan metode informal dan metode formal.

\section{Hasil dan Pembahasan}

Pembahasan pada penelitian ini berdasarkan data yang telah terkumpul. Analisis data dibagi sebagai berikut.

\subsection{Afiksasi dalam Kumpulan Cerpen Cinta Paling Rumit Karya Boy Candra}

Afiksasi merupakan proses pembubuhan kata dengan membubuhkan imbuhan atau afiks pada suatu bentuk, baik bentuk tunggal maupun bentuk kompleks (Ramlan, 1979:30). Afiksasi adalah proses yang mengubah leksem menjadi kata kompleks (Kridalaksana, 2002:28). Afiksasi dalam kumpulan cerpen Cinta Paling Rumit (CPR) karya Boy Candra sebanyak 681 kata (31\%). Dalam data yang ditemukan pada kumpulan cerpen CPR karya Boy Candra ini, proses afiksasi dipaparkan sebagai berikut.

\subsubsection{Prefiks}

Prefiks yang ditemukan dalam kumpulan cerpen Cinta Paling Rumit Karya Boy Candra adalah $\{m e N-\},\{k e-\}$, $\{b e r-\},\{d i-\},\{$ se- $\},\{p e N-\},\{$ ter -$\}$, $\{$ per- $\}$.

Contoh:

$\{p e N-\}+$ jahat $\rightarrow$ /penjahat/ (S:78)

Prefiks $\{p e N-\}$ memiliki fungsi yang berkaitan dengan prefiks $\{m e N-\}$. Prefiks $\{p e N-\}$ berfungsi sebagai pembentuk kata benda seperti data berikut.

Hal yang wajar bagi para penjahat di kota itu (S:78)

Prefiks $\{p e N-\}$ juga memiliki makna 'yang melakukan' seperti data berikut.

a) Hal yang wajar bagi para penjahat di kota itu (S:78). Makna penjahat adalah 'orang yang melakukan kejahatan'.

\subsubsection{Sufiks}

Sufiks yang ditemukan dalam kumpulan cerpen Cinta Paling Rumit karya Boy Candra adalah $\{-a n\},\{-k a n\}$, $\{-i\},\{-n y a\}$.

Contoh:

rasa $+\{-k a n\} \rightarrow$ /rasakan/ (H:258)

Sufiks $\{-k a n\}$ memiliki fungsi sebagai pembentuk kata kerja seperti data berikut.

a) Tak semua hal yang bisa kamu rasakan dam yang kamu lihat harus dimengerti oleh orang lain (H:258). 
Sufiks $\{-k a n\}$ memiliki makna 'menyebabkan' atau 'menjadikan' seperti pada berikut.

a) Tak semua hal yang bisa kamu rasakan dam yang kamu lihat harus dimengerti oleh orang lain ( $\mathrm{H}: 258)$. Makna rasakan adalah 'menyebabkan turut merasakan'.

\subsubsection{Konfiks}

Konfiks yang terdapat dalam kumpulan cerpen Cinta Paling Rumit karya Boy Candra adalah $\{k e-\ldots-a n\}$, $\{$ ber-...-an $\},\{$ per-...-an $\},\{$ peN-...-an $\}$.

Contoh:

$\{$ ber-an $\}+$ hadap $\rightarrow$ /berhadapan/ (CPR:3)

Konfiks $\{$ ber-...-an $\}$ memiliki fungsi sebagai pembentuk kata kerja seperti data berikut.

a) Dia duduk berhadapan dengan kursiku (CPR:3)

Konfiks $\{$ ber-/-an $\}$ memiliki makna 'saling' atau 'berbalasan' seperti data berikut.

a) Dia duduk berhadapan dengan kursiku (CPR:3). Makna berhadapan adalah 'saling hadap'.

\subsubsection{Simulfiks}

Simulfiks yang ditemukan dalam kumpulan cerpen Cinta Paling Rumit karya Boy Candra adalah \{meng-/-kan $\}$, \{di-/-kan $\}, \quad\{$ memper-/-kan $\}, \quad\{$ diper-/kan\}.

Contoh:

$\{$ meng-/-kan $\}+$ kalah $\rightarrow$ /mengalahkan/ (SBA:141)

Simulfiks $\{$ meng-/-kan $\}$ memiliki fungsi sebagai pembentuk kata kerja seperti data berikut.

a) Mengalahkan bisnis kafe-kafe yang dekorasinya sekadar foto-foto yang diunggah ke media sosial (SBA:141).
Simulfiks $\quad\{$ meng-/-kan $\} \quad$ mrmiliki makna 'menjadikan sesuatu' seperti data berikut.

a) Mengalahkan bisnis kafe-kafe yang dekorasinya sekadar foto-foto yang diunggah ke media sosial (SBA:141). Makna mengalahkan adalah 'menjadikan kalah'.

\subsection{Reduplikasi dalam Kumpulan Cerpen Cinta Paling Rumit karya Boy Candra}

Reduplikasi atau yang sering disebut pengulangan merupakan pengulangan bentuk, secara menyeluruh ataupun sebagian, dengan variasi fonem ataupun tanpa variasi fonem. Hasil pengulangan di sini disebut kata ulang, sedangkan bentuk yang diulang merupakan bentuk dasar. Tidak semua kata ulang dapat dengan mudah ditentukan bentuk dasarnya (Ramlan, 1979:39--41). Dalam kumpulan cerpen CPR karya Boy Candra terdapat reduplikasi sebanyak 150 kata (7\%).

\subsubsection{Reduplikasi Seluruh}

Reduplikasi seluruh adalah reduplikasi atau pengulangan secara menyeluruh pada bentuk dasar, tanpa perubahan fonem, dan tidak berkombinasi dengan afiks. Pada kumpulan cerpen CPR karya Boy Candra ini ditemukan reduplikasi seluruh seperti pada contoh sebagai berikut.

a. benar-benar (CPR:2)

b. mentah-mentah (DKKCSIKI:17)

c. marah-marah (SKDU:39)

\subsubsection{Reduplikasi Sebagian}

Reduplikasi sebagian adalah pengulangan sebagian dari bentuk dasar yang hanya salah satu suku katanya saja dan disertai dengan pelemahan bunyi. Pada kumpulan cerpen CPR karya Boy Candra ini reduplikasi sebagian seperti ditemukan contoh berikut. memerah (DKKCSIKI:17) lelaki (DL:264) 


\subsubsection{Reduplikasi yang Berkombinasi dengan Pembubuhan Afiks}

Reduplikasi yang berkombinasi dengan pembubuhan afiks adalah reduplikasi yang terjadi bersamaan dengan proses pembubuhan afiks dan mendukung satu fungsi. Reduplikasi yang berkombinasi dengan pembubuhan afiks. seperti data berikut.

a. Reduplikasi yang berkombinasi dengan prefiks $\{$ ber- $\}$, seperti pada data berikut.
(1) berkali-kali (CPR:9)
(2) bertahun-tahun (H:63)

\subsubsection{Reduplikasi dengan Perubahan Fonem}

Reduplikasi dengan perubahan fonem adalah reduplikasi pada bentuk dasar yang disertai dengan perubahan fonem, baik fonem vokal maupun fonem konsonan. Pada kumpulan cerpen CPR karya Boy Candra ini ditemukan reduplikasi dengan perubahan fonem seperti pada contoh berikut.

(1) lontang-lantung (DKKCSIKI:16)

(2) muda-mudi (HPP:101)

\subsection{Komposisi dalam Kumpulan Cerpen Cinta Paling Rumit karya Boy Candra}

Dalam bahasa Indonesia sering ditemukan gabungan dua kata yang menimbulkan kata baru atau disebut kata majemuk.

Komposisi adalah penggabungan dua morfem dasar yang memiliki makna berbeda agar menjadi satu kesatuan kata dan memiliki makna yang baru. Dalam kumpulan cerpen CPR karya Boy Candra terdapat komposisi sebanyak 93 kata $(4 \%)$.

\subsubsection{Komposisi Nominal}

Komposisi nominal ialah komposisi yang pada satuan kata berkategori nomina. Komposisi nominal dapat dibentuk sebagai berikut. a. Nomina + nomina, misalnya:

(1) ibu kota (DKKCSIKI:26)

(2) kursi rotan (DA:73)

Makna komposisi nominal. Komposisi nominal yang bermakna gramatikal 'anggota dari satu medan makna' misalnya, lereng bukit (DJ:121) dan gedung rektorat (EDM:177).

\subsubsection{Komposisi Nominal Bermakna Idiomatik \\ Misalnya, orang tua (ALYDDDOK:230).}

\subsubsection{Komposisi Nominal Bermakna Metaforis}

Salah satu unsur dari komposisi nominal beberapa digunakan secara metaforis. Misalnya, rumah tangga (P:156), kepala desa (KGDAH:168), dan kepala negara (KGDAH:170).

\subsubsection{Komposisi Adjektival}

Komposisi adjektival adalah komposisi yang satuan klausanya berkategori adjektiva (Chaer, 2008:231). Komposisi adjektival dapat dibentuk dengan bentuk dasar sebagai berikut.

a. Adjektiva + adjektiva, seperti pada data di bawah ini.

tua renta (SDS:289).

Makna komposisi adjektival yang terdapat dalam kumpulan cerpen CPR karya Boy Candra ini adalah komposisi adjektival bermakna gramatikal.

\section{Simpulan}

Proses pembentukan kata yang dibahas dalam penelitiam ini adalah afiksasi, reduplikasi, dan komposisi. Berdasarkan hasil analisis, dapat disimpulkan bahwa afiksasi dalam kumpulan cerpen CPR karya Boy Candra ini sebanyak 681 kata (31\%), reduplikasi yang ditemukan dalam kumpulan cerpen CPR karya Boy Candra sebanyak 150 kata (7\%), dan komposisi yang 
ditemukan dalam kumpulan cerpen CPR karya Boy Candra sebanyak 93 kata (4\%). Kumpulan cerpen CPR karya Boy Candra ini didominasi dengan penggunaan afiks. Hal ini terjadi karena cerpen lebih banyak menggunakan bahasa sehari-hari. Berbeda dengan karya satstra lain, misalnya puisi yang biasanya digunakan bahasa yang lebih banyak mengandung diksi.

\section{Daftar Pustaka}

Candra, Boy. 2018. Cinta Paling Rumit. Depok: Kata Depan.

Chaer, Abdul. 2008. Morfologi Bahasa Indonesia (Pendekatan Proses). Jakarta: PT Rineka Cipta.

Chaer, Abdul. 2012. Linguistik Umum. Jakarta: PT Rineka Cipta.

Kridalaksana, Harimurti. 2002. Pembentukan Kata dalam Bahasa Indonesia. Jakarta: PT. Gramedia Pustaka Utama.

Ramlan, M. 1985. Morfologi Suatu Tinjauan Deskriptif. Yogyakarta: UP Karyono. 